\title{
Financial Inclusion Access: Solution for Sustainable Livelihood Development for Disadvantaged Workers: An Empirical Research Survey in Binh Duong province Vietnam
}

\author{
Hong Thu Nguyen \\ Graduate Affairs, Thu Dau Mot University \\ Binh Duong, Vietnam
}

\begin{abstract}
Financial inclusion access provides services and products to all subjects in a convenient, appropriate and effective manner. This paper aims to test the hypothesis that financial inclusion access contributes to the livelihood development of disadvantaged workers. The paper uses quantitative methods in research with secondary and primary data sources through a practical survey of financial inclusion access in disadvantaged groups. The total observed sample is $\mathbf{3 2 5}$ samples, statistical methods and testing of research hypotheses by analyzing probability prediction from Binary Logistic binary regression model results.The research results have brought more job opportunities for working people, at the same time, the study also found the impact of financial inclusion access on the ability of improving education levels and especially the promulgation of the institutional policies, or increasing financial inclusion access to disadvantaged workers through the empirical research result in Binh Duong province.
\end{abstract}

Key words: Financial inclusion, livelihood, disadvantaged workers.

\section{INTRODUCTION}

Financial inclusion is the government's top concern in countries around the world (Fernando, Nimal A. 2009; Chakrabarty, 2013; Khandare, 2019). Financial inclusion refers to the way people can use and gain full access to quality financial services, which is offered at affordable prices and convenience. It helps people manage their resources effectively and establish their own financial management capabilities (Chakrabarty, 2013). The lack of understanding financial inclusion in a large proportion of working-age adults with access to financial activities limits their ability to develop livelihood. Financial inclusion is considered as one of the effective ways to reduce poverty, supply funds for those having demand and meet economic development needs promptly or stabilize family life.

According to the World Bank report (2018), 69 percent of adults have bank accounts in the world. In Thailand, India, Kenya and China, about 80 percent of the population has an account. Statistics in Vietnam, around 40 percent of the adult population have an account. In the Strategic Plan of Financial Inclusion Development Orientation to 2030, the Government of Vietnam sets out a goal that there is at least 80 percent of adults will have transaction accounts at banks or other licensed financial institutions; at least $50 \%$ of the total communes have financial service points; at least $25 \%-30 \%$ of adults deposit at savings credit institutions; the number of non-cash transactions reaches $20 \%-25 \%$ 
Nguyen, H. T. (2020). Financial Inclusion Access: Solution for Sustainable Livelihood Development for Disadvantaged Workers: An Empirical Reasearch Survey in Binh Doung Province Vietnam. Advances in Social Sciences Research Journal, 7(3) 321-329

annually; at least 250,000 small and medium-sized enterprises have outstanding loans at credit institutions; outstanding loans for agricultural and rural development out of total loans of the economy reached 25\%; the average gross written premium of GDP reached $3.5 \%$. It means that the policy of the Party and the State are focusing on strengthening a developed economy with the majority of people in the country having access to the utilities of the financial system conveniently and easily. In particular, paying attention to promote strongly those who are less able to access the services of the financial system such as the poor, the disadvantaged people living in rural and remote areas, small and medium enterprises, cooperatives, small businesses.

According to The General Statistics Office of Vietnam in 2019, there were about 53.3 million employed laborers, of which more than 25.86 million are female workers (accounting for 48.5\%), about 13.5 million young people have jobs (accounting for two-thirds of Vietnam's youth). Besides, among the labor groups in general, the disadvantaged groups are those who need the most support and care as they have unstable jobs or are facing many difficulties in looking for jobs and vocational training opportunities as well as they can be the main working objects that bring income to support their family.

In Binh Duong province, a place located in the southern key economic region of Vietnam has a high economic growth rate approximately $61 \%$ of the working age population, among that, the group of trained workers accounts about $20.7 \%$. Basing on practical facts, most of the disadvantaged workers live in rural areas, industrial parks or low-income concentrated labor areas so they should be supported by policies, especially credit policies, to help them obtain not only abilities but also opportunities to stabilize family life. Stemming from this issue, fostering the work of strengthening financial inclusion access towards the goal of the National Financial Inclusion Development Strategy, this paper will examine the current situation of financial inclusion access to disadvantaged labor group in Binh Duong, which aims to enhance financial inclusion access to social economic development within Binh Duong province.

\section{LITERATURE REVIEW}

The Reserve Bank of India (2008) defines financial inclusion as the process of ensuring access to appropriate financial products and services necessary for residential communities in general, and the vulnerable groups in specific. Chakrabarty (2013); Khandare (2019); Planning Commission (2009) said that financial inclusion includes access to financial services at a reasonable cost for customers. These include not only banking products, but also other financial services like insurance and equity products.

Chakraborty (2011) argues that financial inclusion is the process of ensuring access to appropriate financial products and services necessary for all classes in a fair and transparent manner. Fernando, Nimal A. (2009) financial inclusion provides services quickly and smoothly to increase employment opportunities, business investment opportunities and economic development, especially for vulnerable and low - income beneficiaries to help them increase the quality of life as well as stabilize their family economy (Nicholas, M. at al, 2017). 
In view of Worlbank (2017), financial inclusion means that individuals and businesses have access to useful financial products and services at reasonable prices, which is expressed through services such as: Money transfers, payments, savings, credit and insurance, they are offered responsibly and sustainably. In that view, financial inclusion is expressed through 03 criteria: (1) access to financial services; (2) use of financial services; and (3) the quality of the product and delivery service. Financial inclusion demonstrates access to account transactions, which is the first step towards comprehensive financial expansion as trading accounts allow people to save, send money and receive transactions payment. That causes account holders will be more likely to use other financial services such as credit and insurance to start or expand investment opportunities, manage risk issues and overcome unexpected shocks in life, for example, natural disasters or illnesses to improve their quality of life.

Allen et al. (2014) report that financial inclusion access services stimulates entrepreneurship, creates capital accumulation and enhances the value of assets for those currently suffered from financial exclusion. The lack of financial access is often found in semi-urban and rural areas, agriculture and the informal sector. Financial inclusion provides access to affordable financial services so that excluded individuals have the ability to use more efficient forms of savings as well as concern loans relating to risky business ventures and improve their livelihoods (Nicholas, M. at al, 2017).

Brune et al. (2011) reported that the factors of affecting access to financial services are high transaction costs, limited knowledge and low income. There is a huge of evidence to show that financial inclusion access helps improve the quality of livelihood (Dupas and Robinson, 2013). Financial access in women will develop entrepreneurship in Kenya that leads to greater business investment and higher income.

Weak labor is a group of workers finding difficulties in creating, seeking employment opportunities and maintaining employment in the labor market. Weak labor has particular characteristics or due to the context of social and natural conditions that affect the opportunity to create, seek and maintain employment in the labor market. Specific characteristics may be due to objective conditions such as gender, ethnicity and disability. Natural and social conditions such as poverty, migration, mountainous areas, rural areas or other conditions such as drug addiction, parole.

Livelihood for labor is still one of the issues that need to be discussed and studied. Discussing the livelihood perspective of labor is still a concept viewed from many different perspectives and there is not yet a standard to quantify in a specific way. The livelihood of workers in view of the CRD (Center for Rural Development in Central Vietnam) explains that livelihood is a collection of all the resources and capabilities that labor has, which is combined with decisions and activities they conduct to make a living as well as to achieve their goals and aspirations. Chambers and Conway (1992) argue that simple livelihood is a way of earning money through the ability of finding jobs, increasing assets and increasing income. According to Sustainable Livelihood Analysis Framework of DFID (2001), labor livelihoods include capabilities, physical and social resources, and activities necessary to make a living. The livelihood of a household is a collection of human resources and 
Nguyen, H. T. (2020). Financial Inclusion Access: Solution for Sustainable Livelihood Development for Disadvantaged Workers: An Empirical Reasearch Survey in Binh Doung Province Vietnam. Advances in Social Sciences Research Journal, 7(3) 321-329

capabilities combined with the decisions and activities that they will take to not only make a living, but also to achieve various desires. In other words, the livelihood of a worker or a household is also called the way of earning money of a worker or a household.

In this study, the livelihoods of disadvantaged workers are reflected by job opportunities, education, income status and the influence of local government's policy institutions. In Binh Duong province, an empirical survey data with 325 observation samples belongs to disadvantaged workers show that over $23.7 \%$ of workers in disadvantaged groups completed grade 9 , over $56 \%$ of workers completed grade 12 , over $84 \%$ of the labor force has passed vocational training classes. In 325 surveyed people, over $84 \%$ of respondents knew how to use banking services. Employment of surveyed groups shows that over $54.8 \%$ are self-employed, $29.8 \%$ are workers and the remaining 16\% are unemployed (Table 1).

Table 1. Statistics on employment and education of workers

\begin{tabular}{|l|l|l|l|}
\hline $\begin{array}{c}\text { Employment status of surveyed } \\
\text { people }\end{array}$ & Percent & $\begin{array}{c}\text { Educational level of the subjects } \\
\text { surveyed }\end{array}$ & Percent \\
\hline Freelancer & 54,8 & Elementary & 0,6 \\
\hline Worker & 29,8 & Middle school & 30,9 \\
\hline Unemployment & 16,3 & High school & 68,6 \\
\hline
\end{tabular}

Source: Survey data in 2019

\section{METHODOLOGY}

The paper uses quantitative methods in research with secondary and primary data sources through a practical survey of financial inclusion access in disadvantaged groups in Binh Duong in 2019. The total observed sample is 325 samples, statistical methods and testing of research hypotheses, testing the financial inclusion access level with the development of livelihoods for disadvantaged workers in Binh Duong province by analyzing probability prediction from Binary Logistic binary regression model results.

From the concept of livelihood expressed through labor activities, job seeking opportunities or job training opportunities of workers contribute to increase income sources for the family. In this study, livelihoods are mentioned with the hypothesis that employment opportunities increase with access to general financial services (financial inclusion), and financial inclusion access can improve the educational level of labor or raise labor income.

At the same time, Sundaram and Sriram (2008); Brune et al. (2011) consider that barriers for lack of access to finance are identified as unemployment, low levels of knowledge and low income levels. In other words, financial inclusion measurement criteria are defined as opening banking accounts, using payment services such as ATM cards, internet banking services, money transfer services, make a deposit, save money. From here, the research model is established through a summary of the hypothetical variables in the research model shown in Table 2. 
Binary Logistic regression model, the estimation of financial inclusion access is determined by the formula:

$$
Y=\beta 0+\sum_{i=0}^{n} \beta i X i+u
$$

Where,

Value Y: Comprehensive financial access, binary regression model with dependent variable $Y$ receiving 0 and 1 values.

$\mathbf{X}_{\mathbf{i}}$ values: Independent variables.

Value $\beta_{0}$ : Slope.

Value $\boldsymbol{\beta}_{\mathrm{j}}$ : Regression coefficient.

According to Cox, D.R (1970), the general form of the Binary Logistic regression model is:

$$
\operatorname{Ln}\left[\frac{P(Y=1)}{P(Y=0)}\right]=\beta_{0}+\beta_{1} X_{1}+\beta_{2} X_{2}+\ldots \beta_{n} X_{n}+u
$$

In which, $\mathrm{P}(\mathrm{Y}=1)=\mathrm{P0}$ : Probability of financial inclusion access; and $\mathrm{P}(\mathrm{Y}=0)=1-\mathrm{P}$ : Probability without financial inclusion access.

$$
\begin{gathered}
\operatorname{Ln} \frac{\mathrm{P} 0}{\mathrm{P}(1-\mathrm{P} 0)}=\operatorname{Ln}\left[\frac{\mathrm{p}(\text { access })}{\mathrm{p}(\text { without access })}\right]=\beta 0+\beta 1 \mathrm{X} 1+\beta 2 \mathrm{X} 2+\ldots \beta \mathrm{nXn} \\
\text { Set } 0_{0}=\frac{\mathrm{P} 0}{1-\mathrm{P} 0}=\frac{\mathrm{P}(\text { access })}{\mathrm{P}(\text { without access })} ; \text { with } 0_{0} \text { : Odds ratio } \\
\operatorname{LnO}_{0}=\beta_{0}+\beta_{1} \mathrm{X}_{1}+\beta_{2} \mathrm{X}_{2}+\ldots+\beta_{\mathrm{nXn}}+\mathrm{u}
\end{gathered}
$$


Nguyen, H. T. (2020). Financial Inclusion Access: Solution for Sustainable Livelihood Development for Disadvantaged Workers: An

Empirical Reasearch Survey in Binh Doung Province Vietnam. Advances in Social Sciences Research Journal, 7(3) 321-329

\section{Table 2. Variables in the research model}

\begin{tabular}{|c|c|c|c|c|}
\hline $\begin{array}{c}\text { Variable } \\
\text { symbol }\end{array}$ & $\begin{array}{c}\text { Observation } \\
\text { variable } \\
\text { name }\end{array}$ & $\begin{array}{c}\text { The fundament of } \\
\text { selecting variables in } \\
\text { paradigm }\end{array}$ & The unit of measurement & $\begin{array}{c}\text { Expected } \\
\text { sign }\end{array}$ \\
\hline
\end{tabular}

Y: Dependent variable: Financial Inclusion access (binary variable) receives the values 1 or 0 through access to financial services such as: having a bank account or using ATM services or using digital technology devices in transactions.

Independent variables (livelihood variables of disadvantaged workers):

\begin{tabular}{|c|c|c|c|c|}
\hline $\mathrm{X} 1$ & Age & \multirow{5}{*}{$\begin{array}{l}\text { Chambers } \\
\text { and Conway (1992); } \\
\text { DFID (2001); Sundaram } \\
\text { and Sriram (2008); } \\
\text { NHTG (2017) }\end{array}$} & Working age & $+/-$ \\
\hline $\mathrm{X} 2$ & Income & & The income source (million) & + \\
\hline X3 & Education & & $\begin{array}{l}\text { The level of education (the } \\
\text { year that workers studied) }\end{array}$ & + \\
\hline $\mathrm{X} 4$ & Jobs & & $\begin{array}{l}\text { Employment status } \\
\text { (receiving the values } 1 \text { or } 0 \text { ) }\end{array}$ & + \\
\hline $\mathrm{X} 5$ & Policies & & $\begin{array}{l}\text { Local policy institutions } \\
\text { (receiving the values } 1 \text { or } 0 \text { ) }\end{array}$ & + \\
\hline
\end{tabular}

\section{RESULTS}

First, the study tests the results of the probability model of financial inclusion access to livelihoods, the results showed that the model had predictive results of 325 observations and in 46 samples, it was observed that workers have not got any bank accounts, 23 employees were accurately forecasted at the rate of 50\%, in 245 surveyed respondents who had accounts with at least one bank, the model shows that 237 observed samples were correctly predicted at $96.7 \%$ (Table 3 ).

Table 3. Results of research model forecast

\begin{tabular}{|c|c|c|c|c|}
\hline & \multirow[b]{3}{*}{ Observation } & \multicolumn{3}{|c|}{ Forecast } \\
\hline & & \multicolumn{2}{|c|}{ Banking account } & \multirow[b]{2}{*}{$\begin{array}{c}\text { Accuracy } \\
\text { proportion }\end{array}$} \\
\hline & & $\begin{array}{c}\text { Without banking } \\
\text { account }\end{array}$ & $\begin{array}{c}\text { Having } \\
\text { banking } \\
\text { account }\end{array}$ & \\
\hline \multirow{2}{*}{$\begin{array}{l}\text { Banking } \\
\text { account }\end{array}$} & Without banking account & 23 & 23 & 50.0 \\
\hline & Having banking account & 8 & 237 & 96.7 \\
\hline \multicolumn{2}{|c|}{ Overall percent } & & & 89.4 \\
\hline
\end{tabular}

In addition, the explaining level of the model is expressed by the value $\mathrm{R}^{2}$ - Nagelkerke 0.49 , which means $49 \%$ of the change of the independent variables is explained by the model, and the value of -2 Log likelihood is 156,378 have confirmed that the research model is perfectly appropriate (Table 4). 
Table 4. Model Summary

\begin{tabular}{|c|c|c|}
\hline -2 Log likelihood & Cox \& Snell R Square & Nagelkerke R Square \\
\hline $156.378^{\mathrm{a}}$ & 0.285 & 0.490 \\
\hline
\end{tabular}

In table 5, the regression results show that there are three observed variables that are statistically significant: educational attainment, employment status and policy institutions. In which the job observation variable has sig value with a significant level of 0.00 (the expected significant level is more than 99\%) (Table 5).

Based on the results of the regression model, the study conducted a prediction of the probability of comprehensive access to finance with weak labor livelihoods, the observed variables include: education level, policy institutions and job status. In job status has statistically less than 0.05 (expected value is greater than 95\%), which shows that the research hypotheses are consistent with the research results. Particularly, the observed age and income variable of workers are greater than 0.1 (that is, the expected value is more than $90 \%$ ), so the observed age and income variables are not statistically significant in the model. (Table 5).

From here, how much does the research model of labor forecasting affect the total financial access? Assuming an initial probability of $10 \%\left(\mathrm{P}_{0}=0.1\right)$, based on the formula $\mathrm{P}_{1}=\mathrm{P}_{0} \mathrm{E}^{\mathrm{b}} / 1$ $\mathrm{P}_{0} *\left(1-\mathrm{E}^{\mathrm{b}}\right)$ with $\mathrm{P}_{1}$ is the probability of change after financial inclusion access. The table of probability changes is shown in Table 6.

Table 5. Binary Logistic regression results

\begin{tabular}{|l|l|l|l|l|l|}
\hline \multicolumn{1}{|c|}{ Observed variables } & \multicolumn{1}{c|}{ B } & \multicolumn{1}{c|}{ S.E. } & \multicolumn{1}{c|}{ Wald } & \multicolumn{1}{c|}{ Sig. } & \multicolumn{1}{c|}{ Exp(B) } \\
\hline Age & -0.007 & 0.029 & 0.067 & 0.796 & 0.993 \\
\hline Education & 0.335 & 0.114 & 8.684 & $0.003^{(*)}$ & 1.397 \\
\hline Income & 0.000 & 0.000 & 1.752 & 0.186 & 1.000 \\
\hline Policies & 1.988 & 0.658 & 9.123 & $0.003^{(*)}$ & 7.302 \\
\hline Jobs & 2.719 & 0.464 & 34.328 & $0.000\left(^{*}\right)$ & 15.158 \\
\hline Constant & -4.009 & 1.723 & 5.418 & 0.020 & 0.018 \\
\hline
\end{tabular}

The value column (B) in Table 5 shows the influence coefficient of the independent variables when the dependent variable changes, based on the value of the Exp (B) column in Table 5 to make a financial inclusion access forecast. In other words, if other factors remain constant when accessing financial inclusion, the education level of workers can be improved by 0.18 (from $18 \%$, up to $0.8 \%$ ) compared to with an initial probability of $10 \%$, and while other factors remain constant when accessing financial inclusion policies that increase the impact of financial inclusion access to labor, specifically increasing 1.36 (up $126 \%$ compared to the original assumption 10\%). Moreover, the key factor is that the employment situation has a very strong probability of impacting on financial inclusion access with an initial probability of $10 \%$, provided that other factors remain constant. Financial inclusion increases the employer's ability to find jobs by 2.93 (up to 283\% compared to the initial $10 \%$ assumption, see Table 6 ). 
Nguyen, H. T. (2020). Financial Inclusion Access: Solution for Sustainable Livelihood Development for Disadvantaged Workers: An Empirical Reasearch Survey in Binh Doung Province Vietnam. Advances in Social Sciences Research Journal, 7(3) 321-329

In addition, income and age variables have not been found statistically significant in the research model.

Table 6. Results of research model forecast

\begin{tabular}{|l|l|}
\hline \multicolumn{1}{|c|}{ Observed variables } & Probability changing forecast $\left(\mathrm{P}_{\mathbf{1}}\right)$ \\
\hline Education & 0.18 \\
\hline Policies & 1.36 \\
\hline Jobs & 2.93 \\
\hline
\end{tabular}

\section{CONCLUSIONS AND RECOMMENDATIONS}

The research results show that financial inclusion affects employment opportunities of disadvantaged workers and gives them opportunities to learn and improve their education. In particular, in this study, the policies of the State, of all levels of government are one of the best solutions to increase the opportunity of financial inclusion access to all classes, especially for disadvantaged workers. To increasingly promote financial inclusion access or abilities of developing and expanding livelihood for workers, there are some recommendations should be considered:

Firstly, vigorously implementing the State's policies on the plan of implementing the Scheme, through many operational programs of financial institutions, the financial mechanism throughout the country are focusing on diversifying products, services and providing information on products and services in a transparent manner to all components and all subjects in need, also paying attention to the propaganda and dissemination of knowledge for everyone to access and use financial services in a way that suits their individual characteristics.

Secondly, it is clear that financial inclusion access increases great job opportunities for workers so it need to be paid attention between employment policies and financial policies of financial institutions and intermediary financial institutions. This action promotes the development of livelihood resources and enhances financial inclusion access to all strata of the population, especially the disadvantaged labor groups that need to be concerned and facilitated in the current period.

Thirdly, improving the education level for workers is associated with access to financial services in general, or in other words, financial inclusion promotes opportunities for increasing labor education. There are some essential activities for that issue like the need for a synchronous combination of financial policies with education and training, the implementation of financial programs and projects to educational institutions, vocational training institutions, companies, businesses through funding, propagation or holding contests relating to financial policy for all subjects in society, especially, disadvantaged workers in industrial parks, labor areas or low-income residential areas and etc. This solution creates chances for people to grasp and access information of financial service clearly and practically so they can use financial products and service more easily and quickly to promote financial inclusion access targets according to the strategic objectives 
of financial inclusion development scheme in order to command the current trend of society.

\section{LIMITATION AND FUTURE RESEARCH}

The study has shown that financial inclusion access brings many job opportunities for disadvantaged workers in Vietnam, especially Binh Duong. Besides, many research perspectives of financial inclusion give a hand in economic development and poverty reduction, the impact of digital technology on increasing financial inclusion access, etc. This study was initially conducted in a province of Vietnam and the context of following studies the research will expand particular areas, key economic regions or random areas within a nation. They will be done in future studies of new research projects.

\section{References}

Allen, F., E. Carletti, R. Cull, J. Qian, L. Senbet, and P. Valenzuela (2014). "The African Financial Development and Financial Inclusion Gaps." Journal of African Economies 23 (5): 614-642.

Brune, L., X. Giné, J. Goldberg, D. Yang (2011). Commitments to Save: A Field Experiment in Rural Malawi. World Bank Policy Research Working Paper No. 5748. Washington, DC.

Cox, D.R. (1970). The analysis of binary data. Methuen, London.

Chakrabarty, K.C. (2010), 'Inclusive Growth - Role of Financial Sector', Address at the National Finance Conclave 2010, KIIT University, Bhubaneswar on November 27, 2010.

Chakrabarty, K.C. (2011), 'Financial Inclusion', Presentation at St. Xavier's College, Mumbai on September 7, 2011.

Chambers Robert and Gordon Conway (1992). "Sustainable Rural Livelihoods: Practical Concepts for the 21st Century." IDS Discussion Paper No. 296. Brighton, Institute for Development Studies, University of Sussex.

Chakrabarty, K. C.(2013). Financial Inclusion in India: Journey so far and way forward. RBI Monthly Bulletin October 2013.

Dupas, P., and J. Robinson, 2013. "Savings Constraints and Microenterprise Development: Evidence from a Field Experiment in Kenya." American Economic Journal: Applied Economics, 5, 163-92.

Fernando, Nimal A. (2009). "The State of Financial Inclusion in Asia: An Overview." Presentation at the AFI Global Policy Forum. Nairobi, September 14.

General Statistics Office (2019). https://www.gso.gov.vn/default.aspx?tabid=714

Khandare V. B. (2019). Financial Inclusion: Empirical study of brics countries. International Journal of Social Science and Economic Research. ISSN: 2455-8834. Volume: 04, Issue: 05 "May 2019". www.ijsser.org.

Nicholas M. , Khupukile M. And Simon N. (2017). Financial Inclusion And Quality of Livelihood in Zimbabwe.

Sriram, M., \& Sundaram, N. (2015). Financial inclusion index: a customized regional model with reference to economically most backward districts of Tamil Nadu, India. Mediterranean Journal of Social Sciences, 6 (6), 209. Reserve Bank of India (various years). Report on Trend and Progress of Banking in India. 